\title{
How can stakeholders promote environmental and social responsibility in the shipping industry?
}

\author{
Tuuli Parviainen $^{1}$ (D) Annukka Lehikoinen ${ }^{2}$. \\ Sakari Kuikka $^{1} \cdot$ Päivi Haapasaari ${ }^{1}$
}

Received: 10 February 2017 / Accepted: 6 December 2017 /Published online: 18 December 2017 (C) The Author(s) 2017. This article is an open access publication

\begin{abstract}
The highly globalized and competitive nature of the shipping industry poses serious governance challenges. Recently, the use of voluntary measures, such as corporate social responsibility (CSR) initiatives, has been explored in terms of moving towards environmentally and socially responsible as well as safe shipping industry practices. Limited attention has been paid on the role of stakeholders such as consumers, employees, NGOs, and academia in pressuring the shipping industry towards greater environmental and social responsibility. Here, by applying stakeholder theory and drawing on examples of already materialized stakeholder actions and multistakeholder initiatives, we study the potential ways that stakeholders can promote CSR in the shipping industry: we explore the resource dependencies between stakeholders, the stakeholder influence strategies, and the importance of multi-stakeholder pressure. We show that stakeholders can gain more power by using indirect strategies such as working via and/or in alliances with NGOs, trade unions, banks and financers, and/or different national or international regulatory bodies, as well as with the industry itself. Our results reveal the potential of multi-stakeholder pressure and action to promote the adoption of CSR activities, support the transparency, legitimacy, and enforcement of the practices, as well as widen the scope and focus of CSR initiatives and practices by focusing on a broad range of social and environmental issues. Finally, stakeholder pressure can push towards improved regulations. The study suggests that increased attention needs to be paid on the multi-stakeholder demands, especially considering the accentuated importance of effective maritime governance in the future.
\end{abstract}

Tuuli Parviainen

tuuli.parviainen@helsinki.fi

1 Department of Environmental Sciences, University of Helsinki, Finland, P.O Box 65 (Viikinkaari 2a), 00014 Helsinki, Finland

2 Department of Environmental Sciences, Kotka Maritime Research Center, University of Helsinki, Finland, Keskuskatu 10, 48100 Kotka, Finland 
Keywords Corporate social responsibility $\cdot$ Shipping $\cdot$ Stakeholder theory $\cdot$ Multistakeholder framework

\section{Introduction}

The shipping industry is a highly globalized, competitive, and dynamic industry: global shipping transports around $90 \%$ of world trade (ICS 2014). However, the various environmental impacts of the shipping industry are severe, including air pollutant emissions (such as sulfur and nitrogen oxides and carbon dioxide), oil and chemical cargo discharges, and litter, sewage, and invasive species in ballast water (Andersson et al. 2016). Furthermore, the industry is characterized by the wide abuse of maritime policies with the use of flags of convenience to avoid national or regional regulation such as Flag State Control measures, tax evasion and the use of tax havens, and the inadequacies and abuse of Port State Control measures. All of these have further contributed to reduced safety levels of shipping activities, social problems such as poor working conditions, and high environmental impacts and risks (Kuronen and Tapaninen 2009; Roe 2008; Sampson and Bloor 2012).

International maritime policies and regulations are mainly set by the United Nations' International Maritime Organization (IMO) and entered into force by nation states. The principle IMO conventions in terms of safety and the environment include the International Convention for the Prevention of Pollution from Ships (MARPOL), the Convention for Safety of Life at Sea (SOLAS), and the International Convention on Standards of Training, Certification and Watch keeping for Seafarers (STCW). However, the IMO regulatory framework has been increasingly criticized for its ineffectiveness in addressing the environmental impacts or the social problems of shipping, such as labor rights issues, as well as ensuring safety at sea: these have remained as static, top-down policies, and too slow to react to changes in the industry (Roe 2013; Kuronen and Tapaninen 2009). For example, the ratification processes of IMO conventions are slow or the conventions are not entered into force due to insufficient ratification among the member nations (Lister et al. 2015). In addition, there is a lack of clear enforcement of the adopted regulations (Det Norske Veritas 2014).

As a response to the failure of IMO regulation, various means to improve safety and to reduce the environmental impact of shipping have been proposed. Kuronen and Tapaninen (2009) projected a need to change the whole safety regime. Roe (2008, 2013) proposed developing a maritime governance system towards multi-level or polycentric governance, and Haapasaari et al. (2015) discussed the potential of a regional risk governance framework in enhancing safety.

Several authors have discussed the role of self-regulation and voluntary actions, such as corporate social responsibility (CSR) practices, in the shipping industry (Fafaliou et al. 2006; Wuisan et al. 2012; Yliskylä-Peuralahti et al. 2015). CSR activities are voluntary initiatives that provide industries and companies with one way to account for environmental and social issues in their economic activities (Aguilera et al. 2007; Aguinis and Glavas 2012; Dahlsrud 2008; McWilliams et al. 2006). Compared to land-based industries, the role of CSR practices has remained limited in the shipping industry (Det Norske Veritas 2014; Lister et al. 2015; Yliskylä-Peuralahti and Gritsenko 2014). 
There is a lack of comprehensive analyses in the literature on the potential ways to initiate the use and adoption of CSR practices in the shipping industry. While some studies have examined the role of industry alliances (Lai et al. 2011; Poulsen et al. 2016), the role of stakeholders from outside the industry, including, NGOs, media, consumers, and local communities in pressuring the shipping industry, has largely been neglected. At the same time, tighter co-operation between the different stakeholders in the shipping industry as well as extending and deepening stakeholder involvement in maritime governance is considered necessary (Roe 2013; UNCTAD 2015; YliskyläPeuralahti and Gritsenko 2014). The aim of this paper is to examineand discuss the potential of multi-stakeholder alliances between both the primary stakeholders (often financial such as shareholders, employees, or customers) and secondary stakeholders (often non-financial such as NGOs, media, and consumers) to promote CSR in the shipping sector. Here, we place particular emphasis on the resource dependencies between stakeholders, stakeholder influence strategies, and the importance of multistakeholder pressure and co-operation. The potential role of the scientific community in the process is discussed.

The paper is based on an extensive literature review. To examine the potential ways in which stakeholders can promote CSR in the shipping industry, we utilize stakeholder theory as an analytic tool. Originated by Freeman (1984), the theory provides a framework for exploring how stakeholders influence firms. Stakeholder theory allows for a new and original way of approaching the question of how stakeholders can gain influence over the shipping industry: we consider the role and influence of stakeholders in the shipping sector in terms of resource dependence (Frooman 1999), search for the key dependencies and communication paths among them, and examine the role of both primary/financial and secondary/non-financial stakeholders. Based on the results, we suggest novel steps for promoting CSR in the shipping sector.

In Sect. 2, we introduce the concept of corporate social responsibility, which has only recently gained some ground in the shipping industry. In Sect. 3, stakeholder theory is applied to identify the potential direct and indirect strategies for stakeholders to pressure industries and corporations into adopting environmentally and socially responsible practices. In Sect. 4, by applying stakeholder theory to the shipping industry, we synthesize and analyze a range of already materialized voluntary stakeholder-driven measures and multi-stakeholder initiatives in the industry. In Sect. 5 , we summarize the roles of different stakeholders and bring forward the potential significance of multi-stakeholder pressure. Finally, in Sect. 6, we provide a route map for further actions and discuss the benefits and limitations of stakeholder participation in developing CSR initiatives in the shipping industry. Section 7 identifies the future research needs and the growing importance of voluntary stakeholder-driven measures in promoting environmental and social responsibility in the shipping industry.

\section{Corporate social responsibility and the shipping industry}

\subsection{Corporate social responsibility}

The use and implementation of CSR practices in different industries has been widely studied (Aguilera et al. 2007; Aguinis and Glavas 2012; Dahlsrud 2008; McWilliams 
et al. 2006). The theoretical perspectives on the use of CSR are varied and have changed through time and space (McWilliams et al. 2006), and no clear-cut definitions exist for CSR. Most commonly, however, CSR is defined as situations where corporations engage in voluntary actions going "beyond compliance" or regulations by actively incorporating social and environmental concerns in their business operations (McWilliams et al. 2006).

In addition to various international, national, or industry-specific guidelines, such as the United Nation's (UN) Global Compact or the Organization for Economic Cooperation and Development (OECD) Guidelines for Multinational Enterprises, CSR methods and initiatives often include financial drivers, environmental and social standards/certifications, and the forming of business associations (Ranängen and Zobel 2014).

Land-based industries with extensive environmental and social impacts, such as the extractive industries, clothing and retail industries, or chemical production, have been at the forefront in developing CSR practices. Land-based industries have often adopted formal written codes of environmental and social responsibility. Some of the most comprehensive CSR practices can be found in the oil and gas industry, but the forest industry is also guided by various initiatives such as forest certifications and ecolabeling (Ranängen and Zobel 2014; Sharma and Henriques 2005). Brand retailers such as Walmart and Unilever have recently emerged as CSR leaders (Dauvergne and Lister 2013).

\subsection{CSR in the shipping industry}

The role of self-regulation and the adoption and implementation of CSR activities in improving safety and reducing the environmental impact of shipping has gained increasing interest among the different actors in the shipping industry, as well as in academia (Acciaro 2012; Kunnaala et al. 2013; Poulsen et al. 2016; Yliskylä-Peuralahti et al. 2015).

In general, environmental and social responsibility in the shipping industry has been found to be motivated by the need to comply with existing and possible future regulations, but also the desire to identify efficiency gains with the use of environmental strategies as well as the goal to gain competitive advantage by establishing a green image (Acciaro 2012). A socially responsible shipping company here refers to a company that actively incorporates social and environmental concerns in its business operations and that, in addition to the financial stakeholders, such as ship owners, shareholders, ports, customers, financers, insurers, and classification societies, also pays attention to the interests of the non-financial stakeholders, such as different environmental and societal stakeholder demands.

However, there are several limitations to the use and effectiveness of CSR practices. Some CSR activities have been considered merely as forms of green-washing, i.e. the gap between concrete actions and symbolic "green" talk (Lyon and Montgomery 2015), as well as the extent to which CSR practices have been effective in changing industry practices, has remained unclear and is continuously debated (Aguilera et al. 2007; McWilliams et al. 2006; Ranängen and Zobel 2014). Similarly, in the shipping industry, the extent to which companies have understood the benefits of CSR practices, as well as the extent to which these can be beneficial, for example, in increasing safety 
or protecting the environment, is not always clear and there is limited empirical data on the benefits of CSR for shipping businesses (Fafaliou et al. 2006).

The highly globalized, dynamic, and competitive nature of the shipping industry poses significant challenges to the adoption and implementation of the CSR- framework: due to the highly competitive environment, shipping companies tend to seek short-term profit, whereas engaging in CSR activities generally produces economic, social, and environmental value in the long term (Kunnaala et al. 2013). Furthermore, both the geographical and regulatory context makes CSR implementation complex. In general, CSR practices in shipping have been found easier to implement in countries and regions where strict regulations and high environmental standards already exist (Yliskylä-Peuralahti et al. 2015).

There are also differences between shipping and operation types. For example, quality standards for oil and chemical tankers are more stringent than those for container or dry bulk ships, and they undergo a number of quality inspections such as classification, port inspection, and vetting practices, where the higher tanker safety standards have led to significant reductions in oil spills (Poulsen et al. 2016). Oil spills are immediately visible to the public, and these improvements are generally considered as the results of joint action between the public, policymakers, and cargo-owners driven by high media visibility (Poulsen et al. 2016).

While oil spill prevention has largely remained the only concern in terms of tanker shipping, the container sector has focused on a wider variety of environmental issues (Poulsen et al. 2016). However, the environmental impacts of dry bulk shipping, including $\mathrm{CO}^{2}$ emissions, invasive species, or the scrapping of vessels, have remained less visible and have been considered largely neglected by the industry, regulators, and public attention (Poulsen et al. 2016).

In addition, even though CSR practices have largely been motivated by the possibility to gain competitive advantage by paying attention to the environmental impacts of the industry, limited attention has focused on the different social issues, including safety at work, labor rights issues, customer relations, the impact of shipping on coastal communities, and the increased transparency of operations (Acciaro 2012; Det Norske Veritas 2014; Roe 2013; Yliskylä-Peuralahti et al. 2015). Even though different forms of international legislation already exist in terms of, for example, increasing the safety of shipping crew, such as the IMO SOLAS (International Convention for the Safety of Life at Sea) Convention, there is a lack of clear enforcement of these practices (Det Norske Veritas 2014).

Stakeholder participation has been emphasized in the various definitions of CSR (Dahlsrud 2008), and it is argued that in order to understand the full societal benefits and implications of the use of CSR, more attention needs to be paid to the role of different stakeholders (McWilliams et al. 2006). Shipping has generally been considered as a business-to-business industry, where non-financial stakeholders have limited influence on industry practices (Acciaro 2012; Poulsen et al. 2016). However, the role of both industry stakeholders and the different secondary/non-financial stakeholders in demanding safe and sustainable shipping practices is increasingly emphasized, for instance by calling for a multi-stakeholder approach and effective data collection, sharing, and dissemination in the shipping industry in order to enhance sustainable maritime transport (UNCTAD 2015).

Roe (2013) argues that the range of stakeholders needs to be extended in improving shipping governance, including the media, politicians, and various interest groups. 
Similarly, Haapasaari et al. (2015) have argued for regionally effective proactive maritime safety governance based on wide-ranging stakeholder participation, and according to Yliskylä-Peuralahti and Gritsenko (2014), there is a need to broaden the scope of governing actors and governing instruments, and for closer cooperation and commitment of different stakeholders in governing the shipping industry. By analyzing the different influence strategies and relationships of resource dependence between stakeholders, this study explores the potential of stakeholder alliances to gain influence over industry practices and highlights the opportunity of multi-stakeholder pressure to improve and pressure the shipping industry into incorporating greater social and environmental responsibility in its actions.

\section{Stakeholder management theory}

Stakeholder theory can be used to identify different stakeholders inside and outside a firm that influence the firm and to explain the types of influence that the different stakeholders exercise over the firm's sustainability practices (Freeman 1984; Frooman 1999; Phillips et al. 2003). Stakeholders are generally classified either as primary stakeholders, who are engaged in a formal relationship with the firm (e.g., shareholders, employees, suppliers, customers, and government bodies) or secondary stakeholders, who have no formal relationship with the firm (e.g., media, NGOs, citizens, and the local community) (Clarkson 1995). Even though the latter (often nonfinancial stakeholders) have largely been considered as secondary by managers in the past, these groups are now becoming more salient in terms of assessing the social and ecological impacts of business (Sharma and Henriques 2005). The theory focuses on balancing stakeholder interests given the extent of the impact on stakeholders and their influence, i.e., based on criteria rather than seeking balance in a strict sense. Incorporating the broad range of stakeholders demands is considered essential in improving industry practices and supporting the legal and moral interests of stakeholders (Phillips et al. 2003).

The influence strategies that stakeholders use depend on the resource relationship they have with a firm and can therefore either be direct or indirect (Frooman 1999). Stakeholders can be either dependent on or independent of the firm, similarly, a firm can be dependent on or independent of the stakeholders. Therefore, four scenarios of resource interdependence exist between firms and stakeholders: high resource interdependence, low resource interdependence, firm power, and stakeholder power (Frooman 1999) (Table 1).

High interdependence When there is high interdependence between the focal firm and its stakeholders, the most likely strategy for the stakeholders is to directly influence the firm's use of resources and to redefine the common goals. Direct strategies refer to stakeholders themselves manipulating the flow of resources to the firm. Usage strategies refer to strategies where stakeholders continue to supply a resource, but with strings attached, for example, demanding a change in industry practices (Frooman 1999). As both the stakeholders and the firm are dependent on each other, the stakeholders are not able to shut off the flow of resources to the firm. In addition, the cost of changing industry practices tends to be shared between the stakeholders and the firm. 
Table 1 Typology of resource relationships (adapted from Frooman 1999)

\begin{tabular}{|c|c|c|c|}
\hline \multicolumn{2}{|c|}{ Type of resource relationships } & \multicolumn{2}{|c|}{ Is the stakeholder dependent on the firm? } \\
\hline & & Yes & No \\
\hline \multirow[t]{2}{*}{$\begin{array}{c}\text { Is the firm dependent } \\
\text { on the } \\
\text { stakeholders? }\end{array}$} & Yes & $\begin{array}{l}\text { High interdependence } \\
\text { Direct/usage strategies, e.g., } \\
\text { industry/business alliances }\end{array}$ & $\begin{array}{l}\text { Stakeholder power } \\
\text { Direct/withholding strategies, e.g., consumer } \\
\text { pressure or boycotts }\end{array}$ \\
\hline & No & $\begin{array}{l}\text { Firm power } \\
\text { Indirect/usage strategies, e.g., } \\
\text { employees with low } \\
\text { influence }\end{array}$ & $\begin{array}{l}\text { Low interdependence } \\
\text { Indirect/withholding strategies, e.g., NGOs } \\
\text { working in alliances with other } \\
\text { stakeholders }\end{array}$ \\
\hline
\end{tabular}

One example of high interdependence is the formation of strategic alliances and international networks between the industry players themselves, or competitors in order to address environmental problems (Buysse and Verbeke 2003). In fact, there is a tendency for individual managers and firms not to improve their practices before their industry acts collectively (Aguilera et al. 2007). The dominant key players forming alliances also have an important role in disseminating and diffusing CSR practices within industries (Delmas and Toffel 2004), whereas companies resisting the adoption of sustainability practices are in danger of negative corporate reputation which has an impact on firm survival and profitability (Sharma and Henriques 2005; Clarkson 1995).

Stakeholder power If stakeholders control critical resources, but are not dependent on the firm, they can withhold the resources from a focal firm unless it follows certain rules. Withholding strategies are defined as those where stakeholders discontinue or threaten to discontinue providing a resource to a firm if the firm is not willing to change its behavior. With withholding strategies, the firm would be expected to pay the costs of new practices. Withholding strategies include consumer pressure, where consumers exert negative pressure and boycott companies with poor environmental records (Aguilera et al. 2007; Buysse and Verbeke 2003; Sharma and Henriques 2005). For example, Greenpeace led a boycott campaign against Nestlé, as the company used unsustainable palm oil sourced from Indonesia-the campaign resulted in Nestlé adopting new sustainability practices and working towards ending the use of unsustainable palm oil (Greenpeace 2010; Ionescu-Somers and Enders 2012).

Firm power Under the third scenario, the firm and its stakeholders are considered to have no interdependence. Examples include firms or companies operating in a highly competitive environment with lax regulations. Here, indirect and usage strategies are likely to be used by stakeholders, such as easily replaceable employees (versus managers) or minor suppliers. Since the firm has no resource dependence on the stakeholder groups, the firm's sustainability practices are unlikely to be influenced by stakeholder pressure (Frooman 1999). However, failing to support stakeholder participation and management strategies can erode relationships or alienate stakeholders altogether (Hosmer and Kiewitz 2005), or lead to the increased use of confrontational 
strategies by stakeholders such as strikes (Mitchell et al. 1997; Sharma and Henriques 2005).

Low interdependence When focal firms and stakeholders have no interdependence, indirect strategies via other stakeholders are likely. Indirect strategies refer to stakeholders working in alliances or via other stakeholders to influence industry practices. Environmental groups can pressure governmental agencies or large buyers/customers to only operate with companies that adopt sustainable practices. For example, environmental groups targeted large buyers such as Home Depot and Lowe's in the USA so that they would only buy wood products from Canadian companies that had adopted sustainable practices (Sharma and Henriques 2005). Similarly, stakeholder alliances can pressure banks and financers to divest from companies or projects that are not considered responsible.

Stakeholder groups are not static: even if stakeholders, such as easily replaceable employees, initially have little power, they can acquire more by working in alliances or influence industry via other stakeholders (Frooman 1999; Mitchell et al. 1997). In fact, multi-stakeholder dialogue and action have been found effective in pressuring corporations to move towards incorporating greater social and environmental responsibility in their actions (Byster and Smith 2006; Connor 2004; Kong et al. 2002; Raphael and Smith 2006). This is illustrated, for example, the Silicon Valley Toxic Coalition (SVTC) created in response to the use of hazardous chemicals by the electronics industry in the Silicon Valley: the combined pressure of the industry worker's safety advocates, local community activists, community residents, high-tech workers, union members, fire fighters, policymakers, and later on primary stakeholders such as different technology companies, resulted in a change in practices in the electronics industry. Finally, the pressure led to the adoption of new legislation, such as Extended Producer Responsibility (EPR) requiring the recycling of electronic waste (Raphael and Smith 2006; Byster and Smith 2006).

Similarly, Sharma and Henriques (2005) found that in the forest industry, the more advanced sustainability practices, such as eco-design or ecosystem stewardship, were based on pressures from both withholding influence strategies from secondary, nonfinancial, stakeholders (such as consumers, media, local communities, activist shareholders, environmental and social NGOs, special interest groups, and indigenous people), and usage influence strategies applied by primary financial stakeholders, such as customers.

\section{Stakeholder influence in the shipping industry}

\subsection{1. High interdependence}

\subsubsection{Industry alliances}

The key shipping companies working in alliances have an important role in disseminating and diffusing CSR practices within the shipping industry (Table 2). Recently, the International Chamber of Shipping (ICS), the principle international trade association for the shipping industry, committed to reducing 
greenhouse gas (GHG) emissions from the international shipping sector (IMO 2016). This commitment, even though a separate initiative, is consistent with the goals of the UFCCC Paris Agreement (COP 21). Similarly, the Norwegian Shipowners' Association (NSA) has been proactively involved in calling for international regulation on issues such as the scrapping of ships and treatment of ship ballast water (Norwegian Shipowners' Association 2016), and the association was one of the driving forces behind the IMO Hong Kong International Convention for the Safe and Environmentally Sound Recycling of Ships (HKC), which was adopted in May, 2009.

Another example of an industry alliance is the Clean Shipping Project (CSP) (Table 2). The CSP is a business-to-business initiative established in Sweden in 2007 that aims to increase focus on the environmental issues associated with shipping and to improve the environmental performance of marine container transport.

However, initiatives often suffer from a lack of enforcement mechanisms (Lister et al. 2015). Interestingly, there is an example of an industry alliance that especially focuses on the enforcement of regulations: the Trident Alliance is a coalition of mainly Scandinavian shipping owners and operators, and it is committed to the transparent enforcement of maritime sulfur regulations, such as the IMO's SECA (Sulphur Emission Control Area) regulations (Trident Alliance 2016).

Table 2 Examples of different shipping industry alliances (high resource interdependence)

\begin{tabular}{|c|c|c|c|c|}
\hline $\begin{array}{l}\text { Industry } \\
\text { alliances }\end{array}$ & Scope & $\begin{array}{l}\text { Geographical } \\
\text { area of } \\
\text { operation }\end{array}$ & $\begin{array}{l}\text { Focus/issues } \\
\text { covered }\end{array}$ & $\begin{array}{l}\text { Main } \\
\text { stakeholders } \\
\text { involved }\end{array}$ \\
\hline $\begin{array}{l}\text { The } \\
\text { Internation- } \\
\text { al Chamber } \\
\text { of } \\
\text { Shipping } \\
\text { (ICS) }\end{array}$ & $\begin{array}{l}\text { Member shipping companies } \\
\text { operate over } 80 \% \text { of the } \\
\text { world's merchant tonnage }\end{array}$ & Global & $\begin{array}{l}\text { Globalization, climate } \\
\text { change and energy } \\
\text { costs }\end{array}$ & $\begin{array}{l}\text { Ship owners } \\
\text { and } \\
\text { operators in } \\
\text { all sectors } \\
\text { and trades }\end{array}$ \\
\hline $\begin{array}{c}\text { The Clean } \\
\text { Shipping } \\
\text { Project }\end{array}$ & $\begin{array}{l}\text { Container, dry bulk, ro/ro, } \\
\text { cruise }(2000)\end{array}$ & Global & $\begin{array}{l}\mathrm{CO}^{2}, \mathrm{SOx}, \mathrm{NOx} \text {, water } \\
\text { and waste, chemical } \\
\text { use, hull-fouling }\end{array}$ & Cargo owners \\
\hline $\begin{array}{l}\text { Norwegian } \\
\text { Ship } \\
\text { owner's } \\
\text { association } \\
\text { (NSA) }\end{array}$ & $\begin{array}{l}\text { Passenger ships and ferries, } \\
\text { tankers, bulk carriers, dry } \\
\text { cargo ships, offshore service } \\
\text { ships }(>1300)\end{array}$ & Norway & $\begin{array}{l}\text { Safety, environment (air } \\
\text { and water emissions), } \\
\text { anti-corruption, } \\
\text { recycling of vessels }\end{array}$ & Ship owners \\
\hline $\begin{array}{l}\text { Danish } \\
\text { Ship- } \\
\text { owner's } \\
\text { Association } \\
\text { (DSA) }\end{array}$ & $\begin{array}{l}\text { Passenger ships and ferries, } \\
\text { tankers, bulk carriers, dry } \\
\text { cargo ships, other } \\
\text { specialized ships }(>600)\end{array}$ & Denmark & $\begin{array}{l}\text { Environmental issues } \\
\text { (climate, ballast water, } \\
\text { sulfur, recycling), } \\
\text { piracy, the Arctic }\end{array}$ & Ship owners \\
\hline $\begin{array}{c}\text { The Trident } \\
\text { Alliance }\end{array}$ & $\begin{array}{l}\text { Passenger ships, tankers, } \\
\text { bulkers, container ships }\end{array}$ & Global & $\begin{array}{l}\text { Reduction of maritime } \\
\text { sulfur emissions }\end{array}$ & $\begin{array}{l}\text { Ship owners } \\
\text { and } \\
\text { operators }\end{array}$ \\
\hline
\end{tabular}




\subsubsection{Customers}

Some shipping firms are also beginning to adopt green practices in the face of increasing environmental requests from customers, such as cargo-owners and business partners who have a vested interest in their environmental and productivity performance (Lai et al. 2011; Poulsen et al. 2016). Here, cargo-owners generally apply direct usage strategies: the customers demand a change in practices, but due to the resource dependence, they are not able to withhold the supply of resources.

The demands from cargo-owners have resulted in several shipping rating schemes (see Table 3). As a part of the Clean Shipping Project, the Clean Shipping Index (CSI) has been developed, where cargo-owners can select high-ranking shipping companies based on the index: the shipping companies can gain competitive advantage by adopting techniques and practices to reduce the environmental impact of shipping (see Table 3). The CSI therefore creates incentives for other shipping companies to improve their ranking by investing in pollution control measures (Wuisan et al. 2012). Similarly, for example, Walmart, the world's largest retailer, requires shipping companies to be registered under the Clean Cargo Working Group (CCWG) (see Table 3): the CCWG is a business-to-business initiative dedicated to improving the environmental performance of ships and uses a rating scheme to benchmark shipping companies against industry standards. The CCWG represents $80 \%$ of ocean container cargo carriers including 20 of the world's largest container shipping lines (Clean Cargo Working Group 2016).

Apart from the CCWG and ShippingEfficiency.com initiative (providing GHG emission data and ratings for more than 60,000 vessels), the schemes have only started to influence environmental protection in shipping: they cover only a small share of the world fleet, which in total comprises more than 47,000 commercial vessels (of 1000 GT and above) (Poulsen et al. 2016).

Ports can act as leaders in sustainable practices, and the role of ports in sustainable supply chain management has increasingly been explored (Denktas-Sakar and KaratasCetin 2012). For example, the Green Award promotes the highest standards in environmental performance and safety in shipping by rewarding operators who have received the Green Award certification with different discounts and incentives (Green Award 2009) (see Table 3). Ports and other industry actors can provide incentives for vessels that have been awarded with Green Award, such as discounts in harbor dues, lower insurance premiums, or a reduction in the ship's tonnage fee. Similarly, the Environmental Ship Index, which is a benchmarking tool launched by the World Ports Climate Initiative (WPCI), offers vessels with the low emission levels a reduction in port fees. Despite these initiatives, ports have been considered to have a limited influence and to play only a minor role in promoting green practices (Poulsen et al. 2016).

\subsubsection{Banks, financers, and classification societies}

Ship owners and operators largely rely on the banking sector to invest in environmentally friendly technology helping the ships to save on fuel use and reduce air emissions. Financial institutions generally perceive companies with a poor environmental record as riskier to invest in and may therefore demand a higher-risk premium, not invest, or refuse to extend new loans (Buysse and Verbeke 2003). Consequently, commercial banks could play a key role in financing energy-efficient maritime transport systems 
Table 3 Examples of shipping rating schemes

\begin{tabular}{|c|c|c|c|c|}
\hline Rating schemes & $\begin{array}{l}\text { Ship types } \\
\text { and number of } \\
\text { ships }\end{array}$ & $\begin{array}{l}\text { Geographical } \\
\text { area of } \\
\text { operation }\end{array}$ & $\begin{array}{l}\text { Issues } \\
\text { covered }\end{array}$ & $\begin{array}{l}\text { Main stakeholders } \\
\text { involved }\end{array}$ \\
\hline $\begin{array}{l}\text { Clean Cargo } \\
\text { Working Group } \\
\text { (CCWG) }\end{array}$ & Containers (2300) & Global & $\begin{array}{l}\mathrm{CO}^{2}, \mathrm{SOx}, \mathrm{NOx}, \\
\mathrm{PM} \text {, water and } \\
\text { waste, } \\
\text { chemical use }\end{array}$ & Cargo-owners \\
\hline $\begin{array}{c}\text { Clean Shipping } \\
\text { Index }\end{array}$ & $\begin{array}{l}\text { Container, dry bulk, } \\
\text { ro/ro, cruise } \\
(2000)\end{array}$ & Global & $\begin{array}{l}\mathrm{CO}^{2}, \mathrm{SOx}, \mathrm{NOx}, \\
\text { water and } \\
\text { waste, } \\
\text { chemical use, } \\
\text { hull-fouling }\end{array}$ & Cargo-owners \\
\hline $\begin{array}{c}\text { Shippingefficiency. } \\
\text { org }\end{array}$ & $\begin{array}{l}\text { Container, dry bulk, } \\
\text { tankers, general } \\
\text { cargo, ro/ro, } \\
\text { cruise }(>60,000\end{array}$ & Global & $\mathrm{CO}^{2}$ & $\begin{array}{l}\text { Owners and operators, } \\
\text { shippers and charterers, } \\
\text { ports and financial } \\
\text { institutions, classification } \\
\text { societies }\end{array}$ \\
\hline Green Award & $\begin{array}{l}\text { Dry bulk, tankers, } \\
\text { inland barges } \\
\text { and LNG } \\
(>1500)\end{array}$ & Global & $\begin{array}{l}\mathrm{CO}^{2}, \mathrm{SOx}, \mathrm{NOx}, \\
\mathrm{PM} \text { water and } \\
\text { waste, } \\
\text { anti-fouling } \\
\text { paint }\end{array}$ & Ports \\
\hline $\begin{array}{c}\text { Environmental } \\
\text { Ship Index } \\
\text { (WPCI) }\end{array}$ & $\begin{array}{l}\text { Container, dry bulk, } \\
\text { general cargo, } \\
\text { ro/ro, cruise } \\
(>2000)\end{array}$ & Global & $\begin{array}{l}\mathrm{CO}^{2}, \mathrm{PM}, \mathrm{SOx} \\
\quad \mathrm{NOx}\end{array}$ & Ports \\
\hline
\end{tabular}

(UNCTAD 2015). As important sources of funding, private funds and commercial banks could also set higher standards of safety performance as part of the conditions for loans to shipping companies. Classification societies, such as Lloyd's Register, provide assessments and certifications of different international safety and environmental standards for the design, construction, and operation of ships, e.g., different ISO standards (Lloyd's Register Marine 2016). In addition, Lloyd's register has developed its own safety standards. The classification societies could play an important role in improving standards, schemes, and directives in the shipping industry.

\subsubsection{Stakeholder power}

Consumers are increasingly conscious of the ethical and environmental impacts of products and services, and consumer power can have a profound influence on company practices. Consumer pressure in the shipping industry has been considered low due to the business-to-business nature of the industry, as well as the low media visibility of the environmental impacts of shipping (Yliskylä-Peuralahti and Gritsenko 2014; Poulsen et al. 2016). Compared to other shipping industry sectors, the cruising industry sector provides an interesting example in terms of consumer pressure: there is a tighter link between the industry and the consumers and, for instance, direct withholding influence strategies such as consumer boycotts could effectively pressure cruise ships into 
adopting CSR initiatives. Serious attention has been paid on marine safety on cruise ships and cruising is considered a very safe method of traveling (Cartwright and Baird 1999; Lois et al. 2004). As will be illustrated later, consumers can also apply indirect strategies and work in closer co-operation with other stakeholders such as customers, NGOs, media, and regulators and/or influence the shipping industry via these more powerful stakeholders.

\subsubsection{Firm power}

Under the third scenario, where a firm has no resource dependence on the stakeholder group, the firm's sustainability practices are unlikely to be influenced by stakeholder pressure (Frooman 1999). Ship-owners/shipping companies are in a very powerful position in the shipping industry: globalization has enabled ship-owners to take advantage of the regulatory framework and the competitive nature of the industry, i.e., the national flag registers enable the ship-owners to select between countries when registering their fleet (Roe 2013). Consequently, there are two types of companies competing with each other in the shipping market: those companies that are responsible and focus on high-quality shipping and those that focus on providing low-cost services at the expense of safety and the environment (Yliskylä-Peuralahti et al. 2015). The latter are unlikely to be influenced by stakeholder demands.

Furthermore, employee demands are unlikely to influence the companies: under globalization and the relaxed regulatory requirements, seafarers are being sourced from new labor supply nations such as Philippines with comparatively lower salaries (Progoulaki and Theotokas 2010). In addition, the size of the shipboard crew has been dramatically reduced and the profession tends to be characterized by relatively inferior working conditions and high insecurity due to short-term contracts and a high crew turnover (Bhattacharya 2011; Progoulaki and Theotokas 2010). Even though the companies are unlikely to solely be influenced by employee demands, employees can gain power by using indirect strategies: as will be shown later, employees need to work in alliances and be supported by NGOs, trade unions, and/or different national or international regulatory bodies.

\subsubsection{Low interdependence}

In the shipping industry, various examples of successful NGO campaigns and alliances exist where NGOs have used indirect withholding strategies and worked in alliances or via other stakeholders to influence industry practices. NGOs have raised awareness of a broad agenda of environmental and social problems in shipping and have gained power and legitimacy by allying with other NGOs, the public, and/or with transnational regulatory bodies, such as the IMO or the European Commission.

The Clean Ship Coalition (CSC) is a global coalition of several NGOs focusing on a variety of environmental and social issues in shipping, including the protection of marine and atmospheric environments, the safety of shipping operations, sustainable development, and social and economic justice, as well as human health. The CSC was granted IMO observer status in 2010. In addition, the Seas at Risk, a European association of non-governmental environmental organizations, works on multiple maritime issues and launched the "Clean Ship" concept in 2002 focused on ship waste 
dumping: as a result of active lobbying, the concept was included in the European Commission's Communication on an integrated maritime policy for the EU (Seas at Risk 2015). Similarly, the World Wide Fund for Nature (WWF) has globally campaigned for improvements in the shipping industry in terms of calling for sustainable shipping, better practices, and putting an end to flags of non-compliance (WWF 2015). WWF also works together with the IMO and was active, for example, in pushing for the Convention on the Control of Harmful Anti-fouling Systems on Ships, which entered in force globally in 2008 (WWF 2015). In addition, WWF is working with the Sustainable Shipping Initiative, as will be illustrated later.

In terms of the cruise industry, in 2004, the international ocean conservation group, Oceana, successfully persuaded Miami-based Royal Caribbean, the world's second largest cruise ship company, to install wastewater treatment technology in its fleets, and later that year, the state of California passed legislation to stop sewage dumping by cruise ships (Oceana 2004). In the Baltic Sea, following a long HELCOM (the Baltic Marine Environment Protection Commission) process aiming to limit sewage discharges in the Baltic, as well as NGO campaigns (e.g., WWF campaigns) and media attention, all sewage discharges from passanger ships will be banned, as the Baltic Sea special area for sewage discharges from passenger ships under the MARPOL Convention will come into force by 2021 at the latest (HELCOM 2016). Currently, only $30 \%$ of international cruise ships in the Baltic Sea have been reported to use the port reception facilities (HELCOM 2016), while the rest empty sewage directly into the sea.

NGOs and syndicate organizations have also focused on improving social issues and labor rights in the shipping industry. The NGO Shipbreaking Platform is a coalition of 19 environmental, human rights, and labor rights organizations that aim to end the dangerous pollution and unsafe working conditions in shipbreaking. The NGO monitors shipowners and shipping companies and has launched the OFF THE BEACH website, which is targeted at cargo-owners and the public, and provides information on ship-owners (NGO Shipbreaking Platform 2016a). The NGO has also backed a new European Commission Report recommendation for the use of a ship recycling license to promote sustainable shipping recycling: the aim is for all the EU ports to require the license, regardless of the flag of the ship. The current 2013 EU Ship Recycling Regulation requires all vessels sailing under an EU flag to use an approved ship recycling facility, however, the regulation can simply be circumvented by flagging out and using flags of convenience. Therefore, the ship recycling license could provide an effective way of enforcing the polluter pays principle (NGO Shipbreaking Platform 2016b).

Also, the human element and seafarer's rights are now recognized as being closely linked with safety (Sampson and Bloor 2012; Hetherington et al. 2006), and organizations such as the European Transport Worker's Federation (ETF) are working on improving EU labor rights and legislation to also include maritime transport workers. The ETF has pressed for the adoption of a wider regulatory framework in which the competitiveness of the shipping industry would be based on the highest possible standards of safety in both environmental and social terms (European Transport Workers' Federation 2015).

Multi-stakeholder co-operation, including both industry and non-financial stakeholders, and the combination of pressure have the potential to change shipping industry practices. The Sustainable Shipping Initiative (SSI), initiated by a non-profit organization, Forum for the Future, is an example of multi-stakeholder co-operation 
representing a cross-industry group of ship owners, charterers, ship builders, engineers, banking, insurance, and classification societies, as well as the World Wide Fund for Nature(WWF) (Forum for the Future 2017). Major industry representatives such as Maersk Line, Cargill, Lloyd's Register, Wärtsilä, and Namura Shipbuilding are part of the program. The initiative addresses the economic, social, and environmental challenges facing the industry, and is working towards a sustainable shipping industry by 2040 and contributes to the UN Sustainable Development Goals (Forum for the Future 2017).

Finally, the World Ocean Council (WOC) aims at establishing collaboration to address different marine environmental challenges. The WOC is an international business alliance that brings together leadership companies from across the diverse ocean business community to develop industry collaboration in ocean sustainability, science and stewardship. It is a private sector initiative, but the members include commercial, academic, and institutional organizations (World Ocean Council 2017).

Following the 1989 Exxon Valdez incident in Prince William Sound, Alaska, where an estimated 42 million liters (11 million gallons) of crude oil was spilled in the sea, the local residents gained an ally in the government: the stakeholders became influential by receiving support from more powerful stakeholder groups such as the Alaska State government and the court system (Mitchell et al. 1997). An important outcome was the Oil Pollution Act of 1990 (OPA), which provided the federal authorities more legislative power over maritime oil transportation. Furthermore, a stakeholder Steering Committee was formed involving a broad range of stakeholders, including shipping companies, government, the oil industry, local industries, local citizens, representatives of environmental conservation, and the coast guard (Merrick et al. 2001; Merrick et al. 2002). The project was based on cooperative risk management, and the involvement of all stakeholders was found to have resulted in the acceptance of high levels of investment to reduce the risk of further oil spills.

\section{The importance of stakeholder influence}

Globalization, the highly competitive environment, and the weak regulatory framework have contributed to a situation where responsible shipping companies and companies focusing on short-term gains compete in the field of maritime transport. Ship-owners can by themselves or by co-operating with each other in alliances disseminate and diffuse CSR practices within the industry. However, the industry initiatives tend to be limited by the relatively low number of companies participating in them, the lack of enforcement mechanisms, as well as the reluctance of low-cost companies to invest in improving their practices. The evidence from this study suggests that multi-stakeholder pressure can promote the adoption, implementation, and enforcement of CSR practices in the shipping industry.

This study indicates that customers, such as cargo-owners and business partners, can be highly influential if they require responsible practices from the shipping companies they deal with. For example, dry bulk shipping has been mentioned as a sector that is lagging behind in terms of developing sustainability practices (Poulsen et al. 2016), and customer pressure could therefore enhance CSR compliance to become a condition of entry in market partnerships. In addition, the role of ports in sustainable supply chain management can be significant as they can provide incentives for vessels that are 
committed to sustainable practices. The banking sector has a key role in focusing its financing on energy-efficient and ecologically friendly maritime transportation that also address the well-being of crews. Classification societies have the power to set strict safety and environmental standards for the design, construction, and operation of ships.

Consumers, on the contrary, have generally had a limited role in pressuring the shipping industry, although raising consumer awareness of sustainable consumption can to some extent promote the adoption of environmentally and socially responsible practices, especially in the cruising sector. In the current situation where seafarers are often sourced from low-salary countries, the employees have also had very little influence overthe industry practices.

This study has demonstrated how consumers and employees can gain more power by using indirect strategies such as working in alliances with NGOs, trade unions, banks and financers, and/or different national or international regulatory bodies, as well as with the industry itself. The analysis indicates that multi-stakeholder dialog and action (including both financial and non-financial stakeholders) and the combination of pressure can be an influential way to pressure the industry into incorporating greater social and environmental responsibility in its actions (Fig. 1). Alliances between the industry, consumers, local communities, NGOs, trade unions, banks and financers, and policymakers can support the adoption and implementation of CSR practices, increase the transparency, legitimacy, and enforcement of the practices, and contribute to wider discourse on sustainability by focusing on a broad range of social and environmental issues.

Finally, multi-stakeholder pressure, based on both primary/financial and secondary/ non-financial efforts, can lead to advanced sustainability practices and improved regulations: CSR practices help the adoption of new technological improvements, e.g. eco-ships or the use of alternative fuels, but more importantly, CSR practices based on stakeholder pressure, including co-operation with regulators, can be considered as important stepping stones towards tighter social and environmental regulation.

\section{Towards multi-stakeholder pressure}

Our analysis has revealed the potential for multi-stakeholder co-operation and pressure to promote environmental and social responsibility in the shipping industry. The shipping industry has generally been considered as a business-to-business industry, where non-financial stakeholders have had limited influence over industry practices, and pressure from outside the company has seldom been considered to motivate companies to engage in CSR activities (Poulsen et al. 2016; Kunnaala et al. 2013). For example, even though improvements in terms of oil and chemical tanker safety have been viewed as the results of the joint action between the public, policymakers, and cargo-owners, this has been considered as a special case. In comparison to other environmental impacts, oil spills often have high public visibility as they attract wide media attention (Poulsen et al. 2016).

However, we have shown that stakeholders, i.e., consumers or employees with limited initial power, can work in alliances with other stakeholders and/or potentially effectively pressure the industry via other, more powerful, stakeholders. The shipping industry may not be directly faced by secondary/non-financial stakeholder demands, 


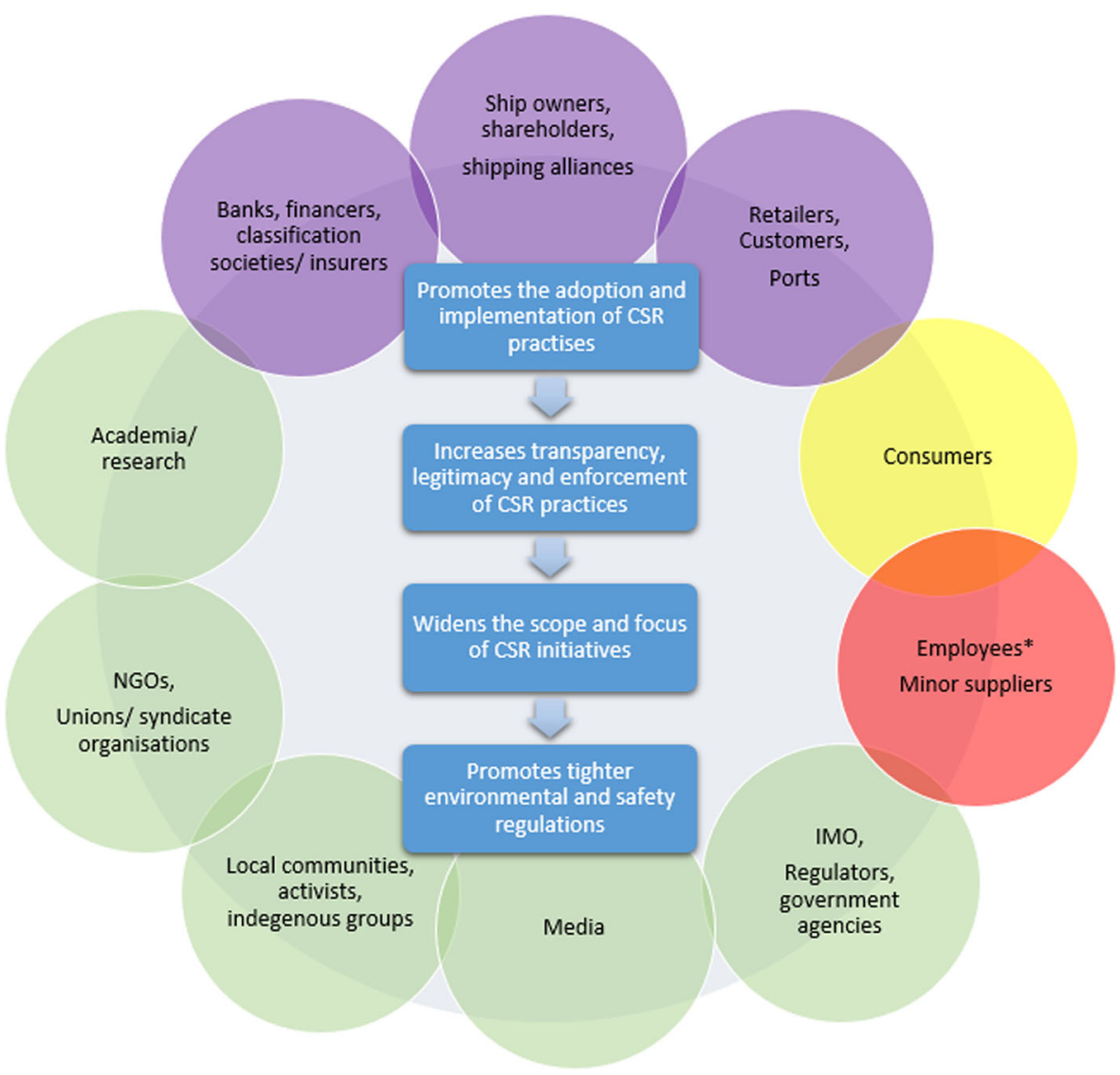

Fig. 1 Multi-stakeholder pressure. High interdependency (purple), stakeholder power (yellow), firm power (red), and low interdependency (green). *Employees here refer to easily replaceable employees (vs. managers)

but the customers are, and the industry therefore also remains to be affected by other than primary/financial stakeholder demands. Furthermore, while stakeholder pressure might not have been considered relevant before, the pressure from both industry stakeholders and non-financial stakeholders has increased in recent years (Kunnaala et al. 2013). Industry initiatives are also increasingly co-operating with non-financial organizations. For example, even though the World Ocean Council (WOC) was developed by the private sector, the WOC network now includes over 35,000 ocean industry stakeholders globally, including intergovernmental bodies, governments, and NGOs (WOC 2017). Therefore, we consider that attending to the different stakeholder demands will be increasingly important for companies that wish to adopt and implement CSR practices and gain strategic benefits by doing so.

We have demonstrated different types of stakeholder dependencies and stakeholder influence strategies in the shipping sector. Nevertheless, the resource dependency system is complex and the dependencies are not static: resource relationships are constantly changing and dynamic in practice. For example, if access to oil reserves is limited due to, e.g., political instability, the relationships are likely to move towards firm power. On the other hand, as new technology is developed or consumer behavior 
changes due to, e.g., NGO and media campaigns, the demand for oil decreases and we move towards stakeholder power. Due to this complexity, describing and analyzing the system, remains a challenge.

In contrast to most land-based industries that have extensive CSR frameworks, the use of responsibility practices has only recently gained some ground in the shipping industry. Evidence of the impact of CSR practices on the efficiency and performance of companies remains scarce. Scientific research is needed to shed light on the short- and long-term impacts of CSR practices and reduce the uncertainty faced by shipping companies related to investments in responsible practices.

This analysis indicates a need for multi-disciplinary research to (1) provide a common definition/formal written codes of CSR, (2) provide indicators that allow the ranking of shipping companies based on their safety and environmental performance, which would help, for example, banks, financers, and classification societies to finance responsible companies and practices, and (3) develop common classification systems, in co-operation with other stakeholders, that provide information, for example, for customers and consumers on CSR practices and help them to make choices between responsible and "irresponsible" companies (Fig. 3).

To be effective, this study suggests that the CSR initiatives should take a comprehensive three-factor approach to responsibility by considering environmental and social responsibility as well as safety (Fig. 2). A holistic set of globally agreed and transparently used indicators would provide a functional tool kit that can help shipping companies to evaluate and improve their CSR practices, as well as help all the stakeholders to make responsible decisions in their business and everyday life. This would automatically create pressure for shipping companies by strengthening stakeholder power (Figs. 2 and 3).

This study further indicates that a multi-stakeholder approach is especially important in terms of issues that have so far been largely neglected by the shipping industry, as multi-stakeholder pressure can help in widening societal goals. As demonstrated, NGO alliances tend to focus on a wide variety of issues and play a critical role in opening space for wider discourses on sustainability, such as social and economic justice, human rights, human health and working conditions, and the transparency of industry practices. Ultimately, transport is a social and political question and depicts the way society chooses to live and trade. Similarly, the interdisciplinary scientific community could have an important role in initiating dialog and communication on the risks and the environmental impacts of maritime traffic, including questions on who should pay for the investment in new technologies to reduce risks or who should pay for the environmental impacts of shipping or the damages caused by possible oil spills.

The role of the different regulatory bodies remains highlighted, as overestimating the role of stakeholder power might release pressure on governments and corporations to enact changes (Dauvergne and Lister 2010). Therefore, the analysis suggests that the IMO can be considered as an important ally for the stakeholders, and that it is essential for the IMO to take the various environmental and social demands seriously in moving towards sustainable industry practices. This study suggests the need for the IMO to proactively support and promote multi-stakeholder co-operation both on international and local/regional scales, including local initiatives and joint actions, such as the formation of multi-stakeholder alliances in Prince William Sound, Alaska (Merrick et al. 2001, 2002), as well as international alliances, such as the Sustainable Shipping Initiative (SSI) and the World Ocean Council (WOC). Moreover, EU legislation on 


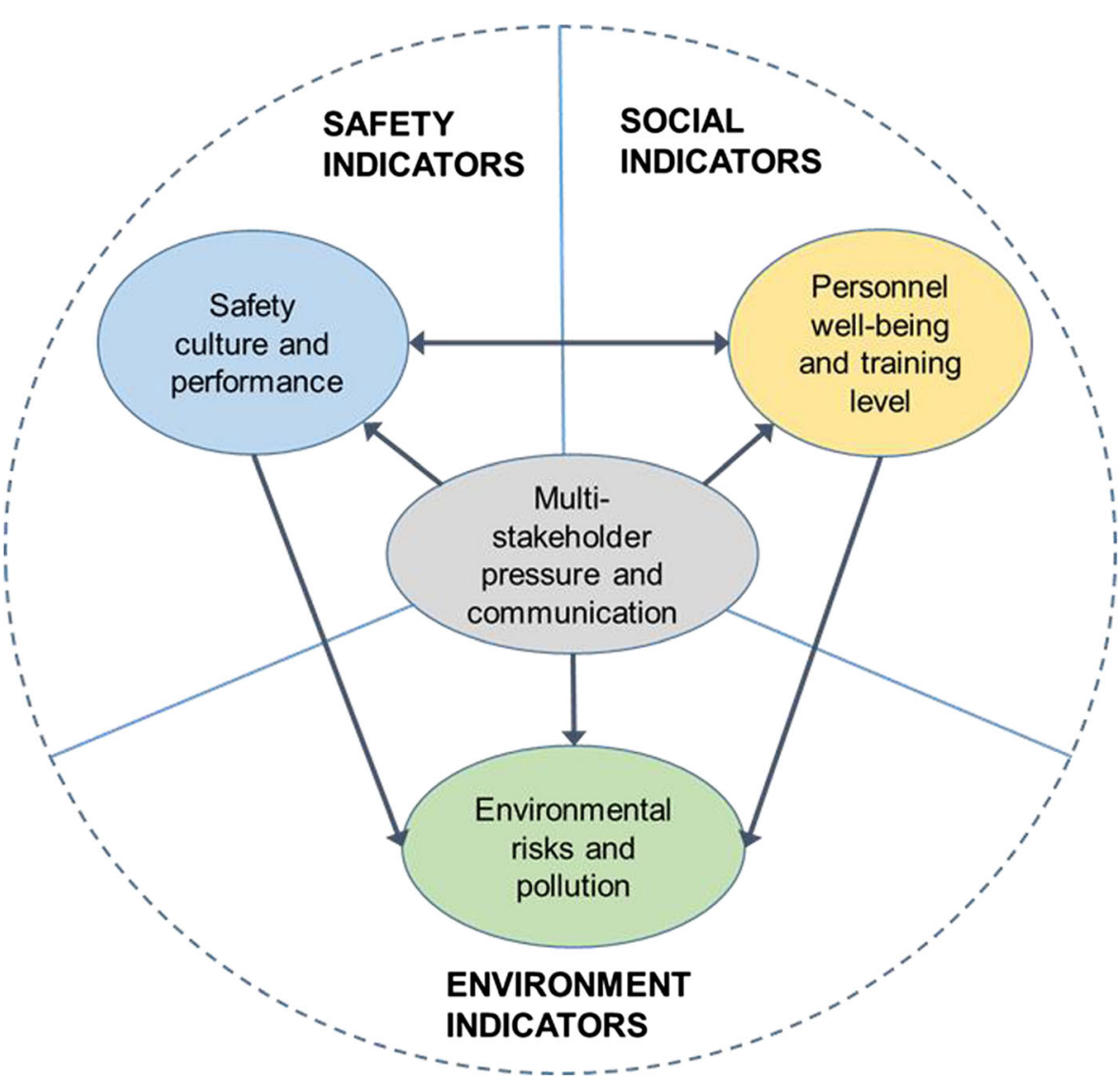

Fig. 2 Suggested holistic indicator approach to define, measure, and communicate the CSR in the shipping industry

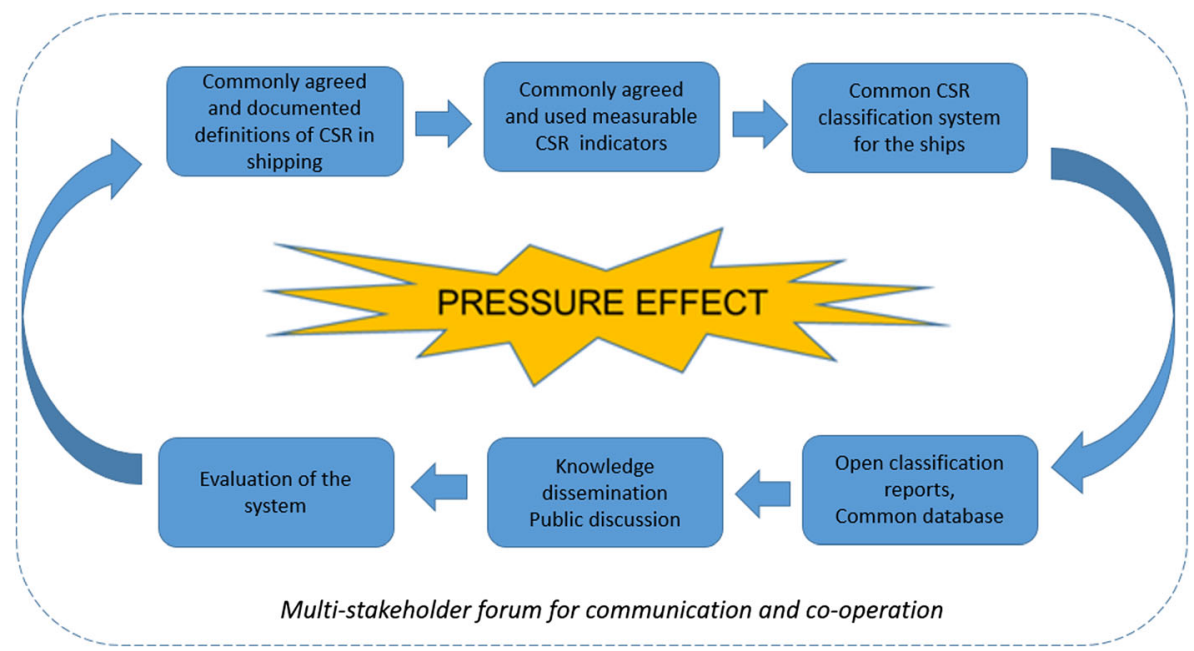

Fig. 3 Suggested global multi-stakeholder forum enhancing the stakeholder power in the shipping sector, by promoting environmental and social responsibility in the shipping industry 
improving seafarers' rights, only applies to ships flying under the EU flag, and its effects on the rest of the industry remain unclear: under globalization and increased competitiveness, with the use of multinational crews together with Flags of Convenience, improving seafarers' rights and considering the human element remain as major challenges for the shipping industry globally, and require regulatory support at both national and international levels.

\section{Conclusions}

The aim of this study was to investigate how stakeholders can promote environmental and social responsibility in the shipping industry. The study revealed the potential for multi-stakeholder pressure to promote environmental and social responsibility in the shipping industry: multi-stakeholder pressure based on both primary/financial and secondary/non-financial stakeholder action promotes the adoption, implementation, and enforcement of corporate social responsibility practices and can push for improved legislation. Multi-stakeholder co-operation can widen the scope of focus of CSR initiatives by drawing further attention to issues that have largely been left unaddressed including, the often-invisible environmental impacts of dry-bulk shipping or social issues, such as, improving the safety and rights of seafarers or the need for increased transparency of operations.

The study has been limited by its focus on corporate social responsibility in the shipping industry in general: due to the diverse nature of the industry, further research on CSR implementation at a finer level is needed, i.e. on the differences between operational types or between regions. Similarly, we have defined corporate social responsibility practices largely in terms of safety as well as environmental and social responsibility, but have paid less attention to the third pillar of CSR, the economic benefits:CSR practices need to be profitable for shipping companies. This study, however, suggests that in the face of stakeholder demands, the shipping industry needs to widen its societal goals and increasingly demonstrate the responsibility of its practices in a transparent manner.

Finally, multi-stakeholder initiatives require time and resources. This study has demonstrated that such initiatives exist at regional as well as international scales, but further research is needed on the effectiveness of multi-stakeholder co-operation, including studies on the process, scope, and depth of stakeholder involvement. In moving towards a more responsible shipping industry, the IMO needs to pay increasing attention to multi-stakeholder demands and initiatives. The importance of responsible practices will be further accentuated in the future due to the expected growth in maritime traffic and the potential opening of new routes in the vulnerable environment of the Arctic Ocean.

Acknowledgements The work of T. Parviainen was supported financially by the Finnish Maritime and Shipping Foundation, the Finnish Foundation for Nature Conservation, and the European Union's Central Baltic Interreg Central Baltic 2014-2020 Programme (project number 94) "30MILES." The research was also supported by the European Union's Central Baltic Interreg IV A Programme (project number CB38) "Minimizing Risks of Maritime Oil Transport by Holistic Safety Strategies." 
We would like to thank the anonymous reviewers for their helpful comments. We would also like to thank Valtteri Laine (HELCOM) and Vappu Kunnaala-Hyrkki (Turku University) for their support and guidance. An earlier version of this paper was presented at the CHIP and MariePRO project "Sustainable Shipping" seminar held by Brahea Center, May 2016, Turku University.

Open Access This article is distributed under the terms of the Creative Commons Attribution 4.0 International License (http://creativecommons.org/licenses/by/4.0/), which permits unrestricted use, distribution, and reproduction in any medium, provided you give appropriate credit to the original author(s) and the source, provide a link to the Creative Commons license, and indicate if changes were made.

\section{References}

Acciaro M (2012) Environmental social responsibility in shipping: is it here to stay? The Quarterly Newsletter of the International Association of Maritime Economists 32(1):27-30

Aguilera RV, Rupp DE, William SA, Ganapathi J (2007) Putting the S back in corporate social responsibility: amultilevel theory of social change in organizations. Acad Manag Rev 32(3):836-863

Aguinis H, Glavas A (2012) What we know and Don't know about corporate social responsibility: areview and research agenda. J Manag 38(4):932-968

Andersson KS, Brynolf JF, Lindgren, Wilewska-Bien M (2016) Shipping and the environment: improving environmental performance in marine transportation. Springer, Heidelberg

Baltic Marine Environment Protection Commission (HELCOM) (2016). Passenger Ship Sewage Discharges into the Baltic Sea Will Be Banned. http:/www.helcom.fi/news/Pages/Passenger-ship-sewage-dischargesinto-the-Baltic-Sea-will-be-banned.aspx. Accessed 28 July 2016

Bhattacharya S (2011) Sociological factors influencing the practice of incident reporting: the case of the shipping industry. Employee Relations 34(1):4-21

Buysse K, Verbeke A (2003) Proactive environmental strategies: astakeholder management perspective. Strateg Manag J 24:453-470

Byster LA, Smith T (2006) From grassroots to global. In: Smith T, Sonnenfeld DA, Pellow DN (eds) Challenging the ship: labor rights and environmental justice in the global electronics industry. Temple University Press, Philadelphia, pp 111-119

Cartwright R, Baird C (1999) The development and growth of the cruise industry. Butterworth/ Heinemann, Oxford

Clarkson MBE (1995) A stakeholder framework for analyzing and evaluating corporate social performance. Acad Manag Rev 20(1):92-117

Clean Cargo Working Group (2016) Clean Cargo Working Group | Collaboration Groups | BSR. http://www. bsr.org/en/collaboration/groups/clean-cargo-working-group. Accessed on 4 August 2016

Connor T (2004) Time to scale up cooperation? Trade unions, NGOs, and the international anti-sweatshop movement. Development in Practise 14(1-2):61-70

Dahlsrud A (2008) How corporate social responsibility is defined: an analysis of 37 definitions. Corp Soc Responsib Environ Manag 15:1-13

Dauvergne P, Lister J (2010) The prospects and limits of eco-consumerism: shopping our way to less deforestation? Organi Environ 23(2):132-154

Dauvergne P, Lister J (2013) Eco-business: abig-brand takeover of sustainability. MIT Press, London

Delmas M, Toffel MW (2004) Stakeholders and environmental management practices: an institutional framework. Bus Strateg Environ 13(4):209-222

Denktas-Sakar D, Karatas-Cetin C (2012) Port sustainability and stakeholder Management in Supply Chains: aframework on resource dependence theory. Asian J Shipping Logist 28(3):301-320

Det Norske Veritas (2014) Corporate Social Responsibility and the Shipping Industry_-project Report. Report No 2004-1535. http://www.he-alert.org/filemanager/root/site_assets/standalone_pdfs_0355-/HE00375. pdf. Accessed 5 March 2016

European Transport Workers' Federation (2015)Maritime transport. http://www.etf-europe.org/seafarers.cfm. Accessed 24 July 2015

Fafaliou I, Lekakou M, Theotokas I (2006) Is the European shipping industry aware of corporate social responsibility? The case of the Greek-owned Short Sea shipping companies. Mar Policy 30:412-419

Forum for the Future (2017) Sustainable Shipping Initiative. http://www.forumforthefuture. org/project/sustainable-shipping-initiative/overview. Accessed 31 May 2017 
Freeman RE (1984) Strategic management: astakeholder approach. Pitman, Boston

Frooman J (1999) Stakeholder influence strategies. Acad Manag Rev 24(2):191-205

Green Award (2009) Green Award: The Pride of the Oceans. http://www.greenaward.org/greenaward/. Accessed 14 January 2016

Greenpeace (2010) Sweet Success for Kit Kat Campaign: You Asked, Nestlé Has Answered.http://www. greenpeace.org/international/en/news/features/Sweet-success-for-Kit-Kat-campaign/. Accessed 22 July 2016

Haapasaari P, Helle I, Lehikoinen A, Lappalainen J, Kuikka S (2015) Proactive approach for maritime safety policy making for the Gulf of Finland: seeking best practices. Mar Policy 60:107-118

Hetherington C, Flin J, Mearns K (2006) Safety in shipping: the human element. J Saf Res 37:401-411

Hosmer LT, Kiewitz CK (2005) Organizational justice: abehavioral science concept with critical implications for business ethics and stakeholder theory. Bus Ethics Q 15(1):67-91

IMO (2016) Reduction of GHG emissions from Ships. http://www.ics-shipping.org/docs/defaultsource/Submissions/reduction-of-ghg-emssions-from-ships.pdf Accessed 31 May 2017

International Chamber of Shipping (ICS) (2014) Shipping, World Trade and the Reduction ofCO2 Emissions: United Nations Framework Convention on Climate Change (UNFCCC).http://www.ics-shipping. org/docs/default-source/resources/environmental-protection/shipping-world-trade-and-the-reduction-ofco2-emissions.pdf?sfvrsn=6. Accessed 14 January 2016

Ionescu-SomersA, EndersA (2012) How Nestlé Dealt with a Social Media Campaign against It. Financial Times. http://www.ft.com/cms/s/0/90dbff8a-3aea-11e2-b3f0-00144feabdc0.html\#axzz4F9G3f64e. Accessed 22 July 2016

Kong N, Salzmann O, Steger U, Ionescu- Somers A (2002) Moving business/industry towards sustainable consumption: the role of NGOs. Eur Manag J 20(2):109-127

KunnaalaV, RasiM, StorgårdJ (2013) Corporate Social Responsibility and Shipping: Views of Baltic Sea Shipping Companies on the Benefits of Responsibility.Publications of the Centre for Maritime Studies, Turku University

Kuronen, J, TapaninenU (2009) Maritime Safety in the Gulf of Finland- Review on Policy Instruments. Publications of the Center for Maritime Studies, University of Turku

Lai K, Lun VYH, Wong CWY, Cheng TCE (2011) Green shipping practices in the shipping industry: conceptualization, adoption, and implications. Resour Conserv Recycl 55(6):631-638

Lister J, Poulsen RT, Ponte S (2015) Orchestrating environmental governance in maritime shipping. Glob Environ Chang 34:185-195

Lloyd's Register Marine (2016) Lloyd's Register Marine. http://www.lr.org/en/marine/. Accessed 14 January 2016

Lois P, Wang J, Wall A, Ruxton T (2004) Formal safety assessment of cruise ships. Tour Manag 25(1):93-109

Lyon TP, Montgomery AW (2015) The means and end of greenwash. Organ Environ 25(2):223-249

McWilliamsA, Siegel DS, Wright PM (2006) Guest editors' introduction: corporate social responsibility: strategic implications. J Manag Stud 43(1):1-18

Merrick JRW, van Dorp JR, Harrald J, Mazzuchi T, Spahn JE, Grabowski M (2001) A systems approach to managing oil transportation risk in Prince William sound. System. Engineering 3(3):128-142

Merrick JRW, van Dorp JR, Mazzuchi T, Harrald J, Spahn JE, Grabowski M (2002) The Prince William sound risk assessment. Interfaces 32(6):25-40

Mitchell RK, Agle BR, Wood FJ (1997) Toward a theory of stakeholder identification and salience: defining the principle of who and what really counts. Acad Manag Rev 22(4):853-886

NGO Shipbreaking Platform (2016a) Off the Beach. http://www.offthebeach.org/. Accessed 29 July 2016

NGO Shipbreaking Platform (2016b) NGO Shipbreaking Platform Press Release - European Commission Report Recommends the Introduction of a Ship Recycling License. http://www.shipbreakingplatform. $\mathrm{org} /$ press-release-european-commission-report-recommends-the-introduction-of-a-ship-recyclinglicense/. Accessed 29 July 2016

Norwegian Shipowner's Association (NSA) (2016) Responsible Recycling of Ships.https://www.rederi. no/en/aktuelt/2016/ansvarlig-resirkulering-av-skip/. Accessed 3 May 2016

Oceana (2004) California Passes Legislation to Stop Cruise Ship Sewage Dumping. http://oceana.org/presscenter/press-releases/california-passes-legislation-stop-cruise-ship-sewage-dumping. Accessed 22 July 2016

Phillips RA, Freeman RE, Wicks A (2003) What stakeholder theory is not. Bus Ethics Q 12(4):479-502

Poulsen RT, Ponte S, Lister J (2016) Buyer-driven greening? Cargo-owners and environmental upgrading in maritime shipping. Geoforum 68:57-68

Progoulaki M, Theotokas I (2010) Human resource management and competitive advantage: an application of resource-based view in the shipping industry. Mar Policy 34(3):575-582 
Ranängen H, Zobel T (2014) Revisiting the 'how' of corporate social responsibility in extractive industries and forestry. J Clean Prod 84:299-312

Raphael C, Smith T (2006) Importing extended producer responsibility for electronic equipment into the United States. In: Smith T, Sonnenfeld DA, Pellow DN (eds) Challenging the ship: labor rights and environmental justice in the global electronics industry. Temple University Press, Philadelphia, pp 247259

Roe MS (2008) Safety, security, the environment and shipping: the problem of making effective policies. WMU J Marit Aff 7(1):263-279

Roe MS (2013) Maritime governance and policy-making: the need for process rather than form. Asian J Shipping Logist 9(2):167-186

Sampson H, Bloor M (2012) The effectiveness of global regulation inthe shipping industry:acritical case study. Revista Latino-americana de Estudos do Trabalho 17(28):45-72

Sharma S, Henriques I (2005) Stakeholder influences on sustainability Practises in the Canadian Forest products industry. Strateg Manag J 26:159-180

Trident Alliance (2016) Trident Alliance. http://www.tridentalliance.org/. Accessed 25 July 2016

United Nations Conference on Trade and Development (UNCTAD) (2015) Review of Maritime Transport. http://unctad.org/en/PublicationsLibrary/rmt2015_en.pdf. Accessed 16 October 2016

World Ocean Council (WOC) (2017) World Ocean Council - The International Business Alliance For Corporate Ocean Responsibility. http://oceancouncil.org/. Accessed 08 June, 2017

Wuisan L, Leeuwen J, van CSA K (2012) Greening international shipping through private governance: acase study of the clean shipping project. Mar Policy 36:165-173

WWF (2015) Better Shipping Practices. http://wwf.panda.org/what_we_do/how_we work/conservation/marine/solutions/sustainable_use/shipping/. Accessed 22 July 2016

Yliskylä-Peuralahti J, Gritsenko D (2014) Binding rules or voluntary actions? A conceptual framework for CSR in shipping. WMU J Marit Aff 13:251-268

Yliskylä-Peuralahti J, Gritsenko D, Viertola J (2015) Corporate social responsibility and quality governance in shipping. Ocean Yearbook 29:417-440 